\title{
Landscape Urban Structure Design - S. Romão Sportive Park, Leiria Polis, Portugal
}

\author{
Rute Sousa Matos \\ University of Évora \\ Art and Art History Investigation Centre (CHAIA) - \\ University of Évora \\ Évora, Portugal \\ rsm@uevora.pt
}

\author{
Paula Simões \\ University of Évora \\ Art and Art History Investigation Centre (CHAIA) - \\ University of Évora \\ Évora, Portugal \\ pmss@uevora.pt
}

\begin{abstract}
It is due to the modern movement the loss of both landscape and open spaces multifunctionality. Consequently, it merges the term of "green spaces" amorphous and residual, often void and without any appropriation, so characteristic of the contemporary city. This study is a reflexion about and a practice result of the return to these spaces multifunctionality through a landscape structure on the urban space. We want this structure to be continuous, structuring and assuring biologic processes and fluxes that occur in the landscape systems. We present the casestudy of S. Romão Sportive Park included in Polis Program of Leiria City, in Portugal. It is a system of open spaces that constitutes itself as a landscape structure, continuous and multifunctional.
\end{abstract}

Keywords- landscape structure, landscape architecture, urban space, open spaces, multifunctionality; S.Romão sportive park

\section{INTRODUCTION}

This paper results of the city study, namely of the relations between the urban fabric and its open spaces. In this study we stand before the importance that the open spaces system has and always had in the city experience and life [1]. In a closer approach to the urban open spaces system we could verify that about them several questions have been raised about their quality and diversity, as a reflex of technologic, economic, social cultural and demographic changes rhythm.

Nowadays the city open spaces are still often called by "green" with an accessory charge and role in the urban space construction. Although its large potential in the city structure and cohesion, these spaces - the open and "green" - are reduced to an index in the municipal statistics due to the indifference attitude before them [1]. It is needed a new understanding about opens spaces condition and about the importance of the landscape quality. We consider fundamental the implementation of an intentional and proper use of theses spaces as a vital condition for its safeguard, in a positive way, assured by its understanding and use, and their recognition as a real potential for the city development, experience and life. They must be faced as spaces of urban cohesion, fundamental and complementary to the urban fabric and its articulation with its surroundings, in ecologically, aesthetically, culturally, socially, economically and technologically terms, what it means they must be multifunctional.
By the bibliographic research with find several authors [1], [2], [3], [4], [5], [6], [7] that look for strategies that lead to landscape and open spaces multifunctionality referring the aesthetic, social, ecologic, economic and cultural components and, consequently to the production, protection and recreation functions. Thus it begins to appear, in this study the idea of open spaces as a landscape fundamental component in the urban space, that qualifies and gives continuity to the urban fabric until the country side promoting an articulated relation between the old dichotomy "city-countryside" [1], [5], [8] e [9]. So, it is our main goal use this approach in a landscape structure proposal for Leiria City urban space, in Portugal, that constitutes a contemporary expression of landscape continuum, because it allows the occurrence of ecologic processes that are fundamental for the sustainable city growth and development [10] e [11].

\section{MethodOLOGY}

This subject importance - the city open spaces, the landscape multifuctionality and the landscape concept as a structure - have led to a reflexion by several authors of the most diversified formations (has we've referred before) leading to the production of bibliography, critical studies and works about these subjects and its importance, namely [1], [2], [3], [4], [5], [6], [7]. As a theoretical support we were interested on the authors that have considered the opens spaces as a work material, with large potential and value for the creation of new sociocultural, economical, ecological and aesthetical viable spaces and the studies that have reflected about the right tools to act on these spaces as human resources. Because they are malleable and flexible spaces, which adaptability, change capacity and articulation with the various systems that constitute the landscape ad its design is a reality not allowed by the rigidity of the urban fabric according to [1], [2], [3], [4], [5], [6], [7], [8], [10], [12].

In the last years were produced some works about the landscape importance in the urban space and about the ecologic systems and aesthetical questions associated to them, namely by [11], [13], [14], [15]. These authors that search for new strategies to get a multifunctional landscape and its understanding defend that in these open spaces should be implanted a continuous and structuring fabric where landscape would be the main structure of this continuum, having has 
concept the landscape systemic vision [1], [5], [7] included in the landscape architecture praxis and philosophy a long time ago, since the first public parks designed by Olmsted, as we can see in [12] until the concept of continuum naturale, introduced and developed by Caldeira Cabral, in Portugal, in the middle of $20^{\text {th }}$ century, including the landscape design related with the concepts of green corridors and green or ecologic structures, all of them essential to the sustainable development of the city according to [9]. Also in Landscape Urbanism in [5] that merges with the relight of the environmental and ecologic concerns, with the growth of tourism and the questions associated to it, with the sense of unicity and entity, as well as with the massive cities growth impact over the countryside, landscape is proposed as a model for urbanism and it's integration in the infrastructure systems is recommended leading and shaping the urban development as what it happened with Olmsted Central Park where the landscape led the city construction process [12], [5], [7].

We can say so that this study was developed from a bibliographic revision based on the subject we intend to develop and in the case-study of S. Romão Sportive Park, designed for Leiria City Polis Program, where are proposed landscape design projects integrated in a landscape structure. For this proposal the methodology used was the in loco analysis of the place recognising its character (physic, social, cultural) its importance in the urban fabric and how the people get appropriated of it as in [16], [17] and [18]. It was made a swot analysis about the strengths, weaknesses, opportunities and threats found in this space. We also consulted the residents involving them in our analysis and proposal. The concept was sketched supported on the bibliographic research and in the space analysis and evaluation and after was discussed by the transdisciplinary team and presented here as a case-study.

\section{STATE OF THE ART}

\section{A. The river as a structure in Leiria city}

"The river is a natural and a cultural landscape that has been a reference for man during his existence. As water source, vital and indispensable element, as a territorial mark that courses and structures the space, as poets and painters' inspiration, they are multiple the dimensions that they represent to society, these so common and singular elements that are in all world landscapes. " [19]

The new perspective under the concept of cities sustainability determined that in Leiria City the relationship with the river would be recovered. A long ecologic, urbanistic and environmental process that promoted and articulated the requalification between the city and the countryside, recovering the relation man-nature, land-water and memory-uses reinvention. A similar process to that was used in USA in the $19^{\text {th }}$ century and leading Europe to valorise the river fronts redesigning the cities aiming recreation but also the resolution of severe social and environmental problems. London was pioneer recovering naval industry brownfields in Thame's margins. The respect for docks image as an historic memory marked that regeneration. They were followed by similar interventions in several European cities: Barcelona, Genoa,
Amsterdam, Oslo, Helsinki, involving large financial and technical investments [19].

In Portugal, having as example Lisbon, was built the Parque das Nações for the Universal Exposition - Expo'98, in a complex process that rehabilitate a polluted, chaotic and industrial area converted in a rubbish deposit - Through the implementation of Polis Program was possible to proceed to the requalification and renovation of this Lisbon area and more other 17 Portuguese cities and its waterfronts [20]. There are several cities that are structured by its rivers [19]. Leiria city morphology it's closely linked to Lis river. This river had a fundamental role in the landscape humanization of the valley where the city is located (Fig. 1).

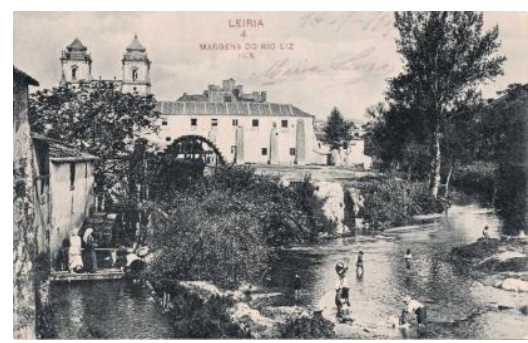

Figure 1. Old postcard of Leria: view over the river and St. Agostinho Convent.

Leiria City is located in the centre of Portugal. It takes advantage of an excellent geographic condition where the economic activity, based on the building construction, still has a strong linkage with agriculture taking profit from the countryside fertility of Lis valley. There are several traces as mills and production structures (Fig. 1 e 2) [21].

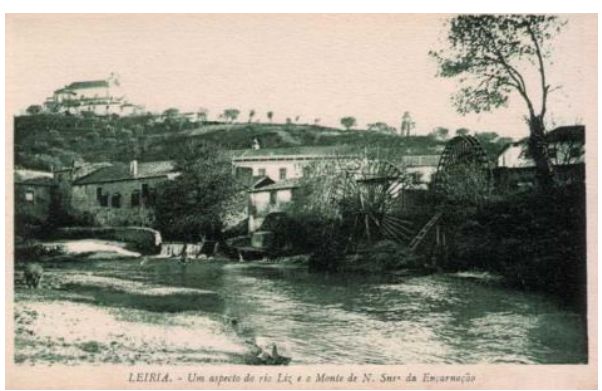

Figure 2. Old postcard: view from the right margin over the river and mill

The political will to improve the quality of life of the population led to the recovery of degraded areas and to the promotion of historic heritage valorisation starting in the river allowing to the increase of the mobility in the urban space as well as the management of one of the more complex river hydrological regime at a national scale.

\section{B. History and Morphology of the City}

Leiria City, Collipo roman city has been developed from a defensive centre strategically located on a spot of physical and visual domain. There are references to this region occupation by people of Celtic and Iberian origin $\left(4^{\text {th }}\right.$ and $5^{\text {th }}$ centuries a.C.). (Fig. 3) 


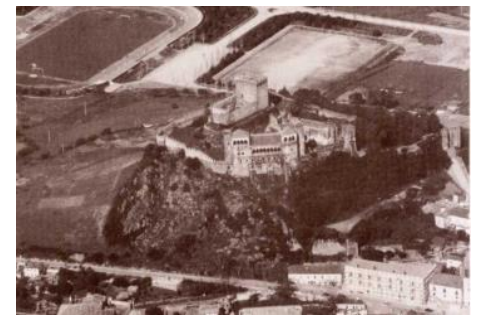

Figure 3. The castle hill as city origin. Postcard from 1968.

Also occupy by Svids and Visigods is known that in 753 was dominated by Moorish people and Córdoba City. The castle, from 1135, was occupied by Moorish and recovered by D. Afonso Henriques in 1142. D. Dinis puts Leiria highlighted in history again when commands the plantation of Leiria Pinewood (1279-1325) as a way to drain and consolidate a large seafront land. The origin of its name it's a memory of the two existent rivers in the old city: Leirena (Lena) and Heirena (Lis). Because of its fertility it had attracted several religious people (churches and convents) that contributed to the way the city is organized (Fig. 1).

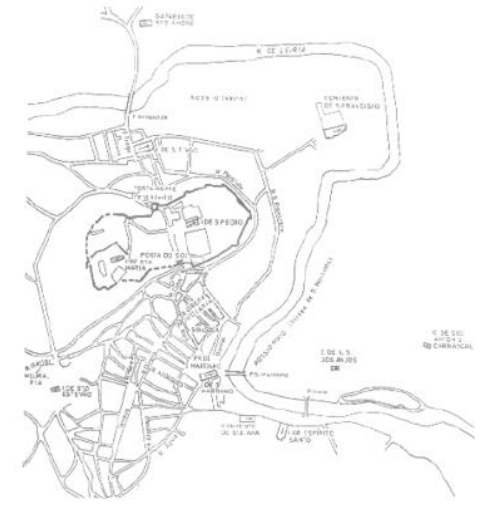

Figure 4. Leiria plan, $15^{\text {th }}$ century. (Source: www.cm-leiria.pt)

Until the $16^{\text {th }}$ century the city grows mainly in the river left margin (Fig. 4). The severe floods in the lowlands led to regularization works on the river, to the diversion of one riverbed section and to works in the river mouth. On $19^{\text {th }}$ century, together with the city growing and structuration of its urban fabric, the public gardens as well as the Marachão pathways were built along the regularized margins. The cross bridges between margins were built too. In the end of $20^{\text {th }}$ century with the loss of professions linked to the river, the city neglected the existent symbiosis relationship, leaving the river to abandon and degradation of its margins, closer lands and its water quality. At the turn for $21^{\text {st }}$ century the need and the will to give back the public space to population captivating her by the introduction of new activities that allowed to Leiria valorise the river, contribute to the urban sustainability and consolidate a continuous ecologic structure in the public hydric domain that would link the city to the rural space offering a set of pathways and cycleway along the river margins where would be also available spaces for recreation and leisure. In short, contributing for the ecologic structure consolidation in a holistic way including the social, economic, cultural and aesthetic functions valorising ecologically and environmentally the river as system structural element [21] [22].

\section{S. ROMÃo SPORTIVE PARK PROPOSAL}

Landscape multifunctionality with a design based on ecologic, social and economic values was the concept used in this landscape project. On a phased way the projects had been implanted complying the proposed interventions: renovation of Lis margins, rehabilitation of the historic centre, restructuration of the road network and create parks and gardens for the population [21]. The rehabilitation covers an urban section, limited at the upstream by the S. Romão bridge and at the downstream by the IC2 (national road) bridge. It has an area with 125ha. (Fig.5)

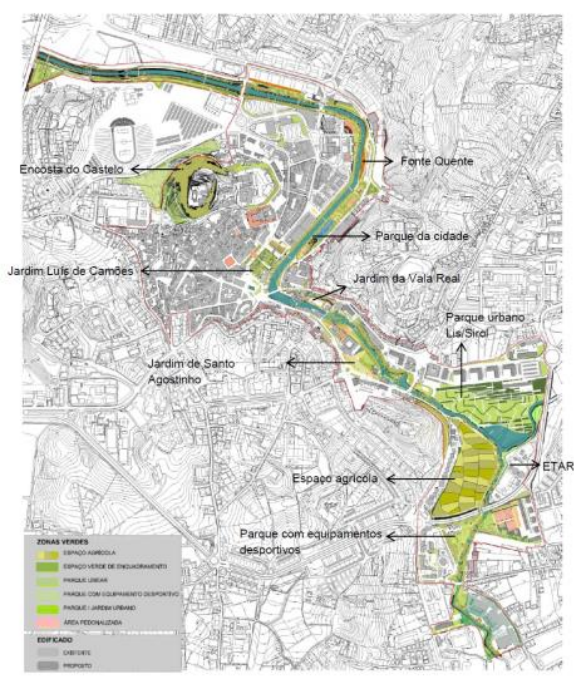

Figure 5. Master Plan of the proposal. Source: Polis Leiria

The Polis program divided the intervention area in four operating units - These Detail Plans (DP) linked with the river are: DP1 - Detail Plan of S. Romão/Olhalvas (Fig.6), DP2 Detail Plan of S. Agostinho, DP3 - Detail Plan of Centre Leiria and DP4 - Detail Plan of Historic Centre. These four plans determinate the intervention priorities and the space organisation proposal that would be the base to the work project to implement. It was still streamlined the project "Bridges Pathway" for all the river area; a proposal which aims the touristic valorisation and the recovery or the creation of the river crossing points. Complementarily to the crossing function the bridges would be also meeting points for thematic information [22].

DP1- The Detail Plan for S. Romão/Olhalvas is located on the upstream of the river and it has 43,1 ha. It is a very permeable and fertile area. The dominant soils are included in the National Agrarian Reserve and on the National Ecologic Reserve and they were used for agrarian production some time ago. Nowadays there are some small allotment gardens and orchards that are irrigated with water that is pumped from the river.

DP1 includes a set of interventions in which is integrated the sportive zone with S. Romão Sportive Park and the Skate Park, in the local where it would be replaced and expanded the municipal tennis complex. Before It was placed in the city core, as well as other equipment and complementary services (Fig.6 and 7). Its replacement in the periphery is part of a 
strategy: It intends to be an attraction pole increasing the pathways along the river, from the city core as well as increasing the sportive equipment which is a city need.

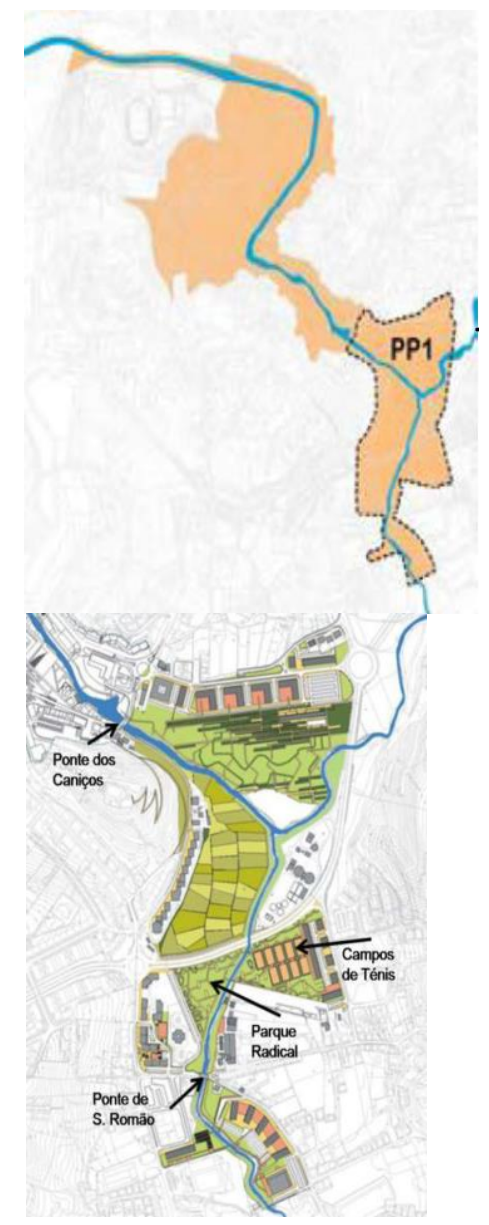

Figure 6. DP1 Intervention area. Source: Polis Leiria
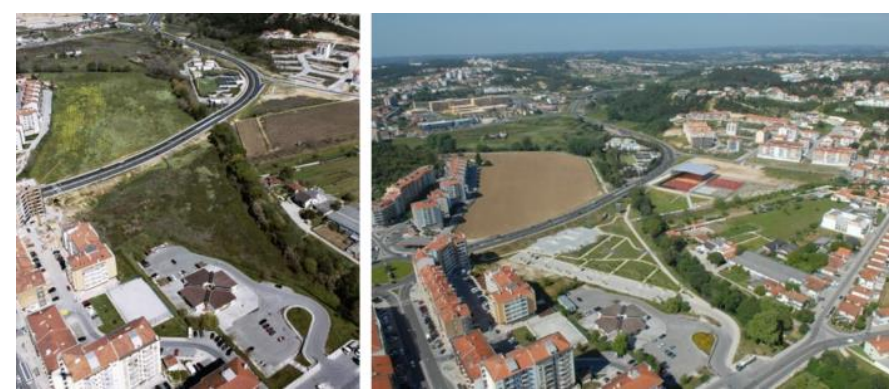

Figure 7. Aerial view over the DP1 sportive area before (left) and after the intervention (right). Photographic credits: Polis Leiria.

The landscape design for S. Romão sportive park, on the right margin of Lis river, in a flood area and left behind by the south road puts in evidence the interdisciplinary approach and the ecological concepts used in its design (Fig.7 and 8). It was the team intention to improve and recover the transversal and longitudinal relations (cultural, physic and ecologic) and maintain the horizontal relations trough the flood plain highlighting the seasons in landscape.

If the place and its cultural and historic memories apply to a rural and agrarian use, to the land permeability and to the connection with the flood regimen (because of the existing vestiges), the definition of the needed equipment in the sportive park program established before determines the regularisation of a large plan, either in area or in its implicit matter. This aware was a challenge in the project design. The landscape architecture, hydric resources engineering and architecture team work have determinate the project design that assured the margins regularisation and stabilization as well as the surrounding areas management.

The torrential regime, as well as the caudal strong variability along the hydrologic year and the bed river strong silting required the prevention of extreme situations what justifies that the park design is structured from the maximum flood line (Fig. 8)

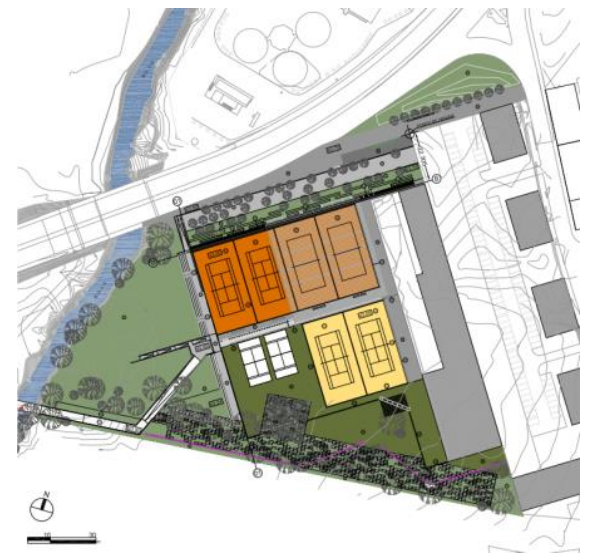

Figure 8. Master Plan

The concrete benches, supported by the construction of a dam, turns to west assuring the flat area where are located the tennis courts (six - two of them covered), the equipment and the buildings (at east) of the health fitness services, restaurant and sports shop (Fig.9).

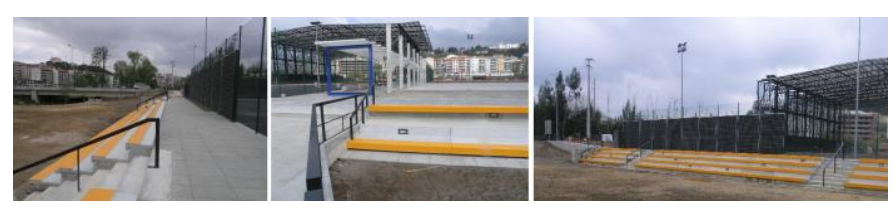

Figure 9. Dam / benches

The dam base quota is based on a landfill regularization in the meadow area (Fig.10). 


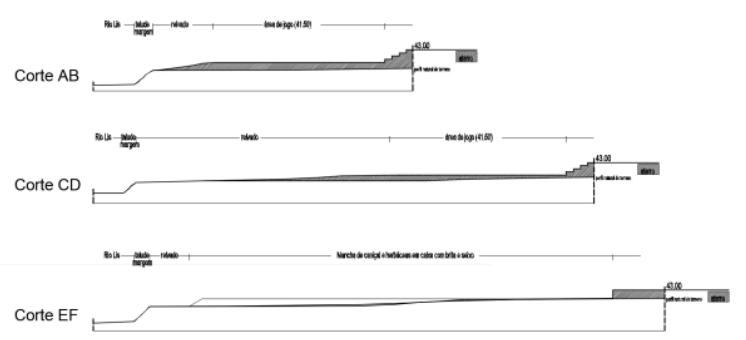

Figure 10. Sections illustrating the landfill in the flood área (meadow).

The tennis court cover is the only build imposition; the rest of all intervention is submitted to a binomial action of recovery/abandon using matters as prefabricated concrete, iron, stone and brick dust.

In the relation with the road were created several acoustic barriers to protect the athletes of the traffic noise. These barriers are built mainly with landfills and vegetation, exploring the different strata. In first place we have a volume of poplar trees, together with a boxwood hedge associated with a basaltic stone wall as it happens in this rural landscape (Fig. 11).

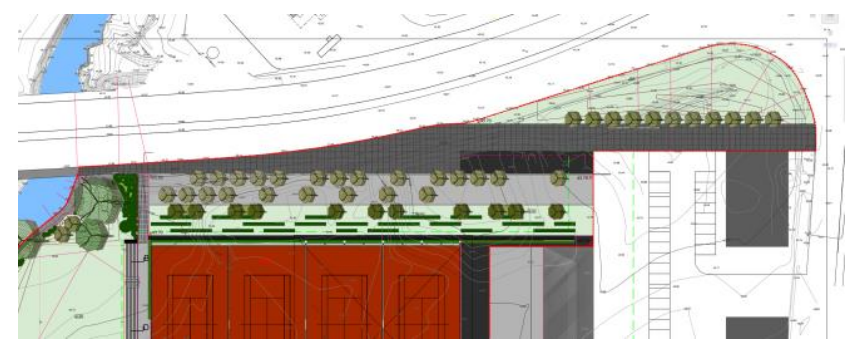

Figure 11. Master Plan. Zoom over the north area.

These volumes end in the acoustic barrier and in a wind guard (Fig. 12, 13 and 15)

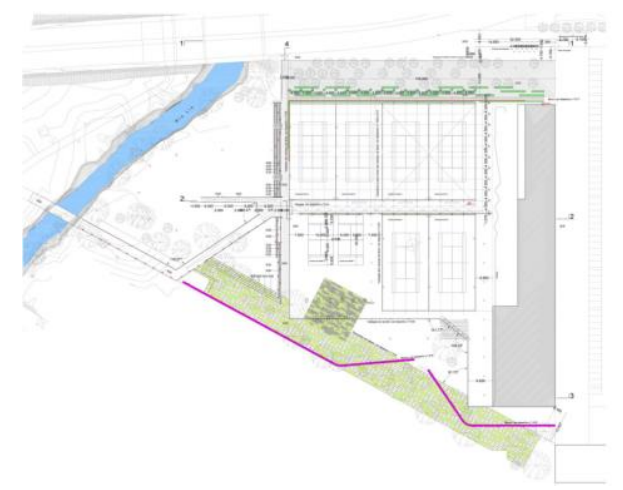

Figure 12. Master Plan

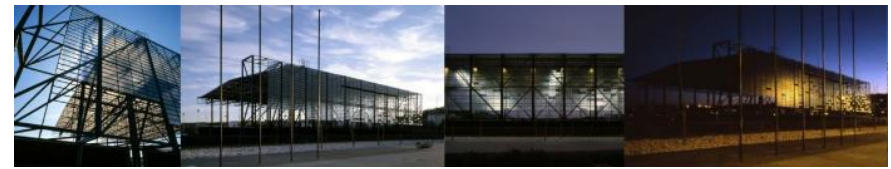

Figure 13. Acoustic barrier and wind guard panel for the game fields protection. Photographic credits: Catarina Costa Cabral
The relation with the river is visually guaranteed by the vertical plan formalized by riparian gallery. We can read the river way from the gallery and beyond the park limits. Physically we accede to the park from the bridge, and from the left margin trough the pathway system. After crossing the bridge, we have a meadow between the bridge and the tennis courts that we can cross in a dominating situation through a walkway, even in flood situations. The technical resolution of this construction assures the water fluxes and the bed river seasonal water logging, safeguarding the space. A hidden trench manages the water way, contributes to soil drainage and damps the oscillations of the water. It contributes for the periphery soil drainage. A net of drains dampens the water level in the meadow (Fig. 14 and 15).

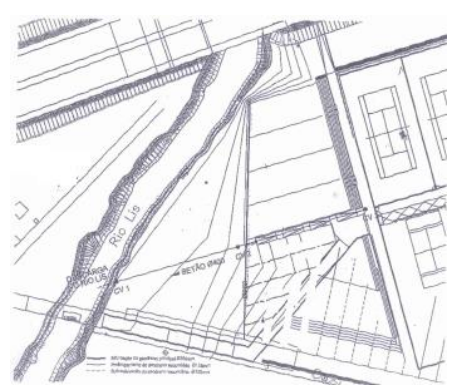

Figure 14. Intern drainage scheme.

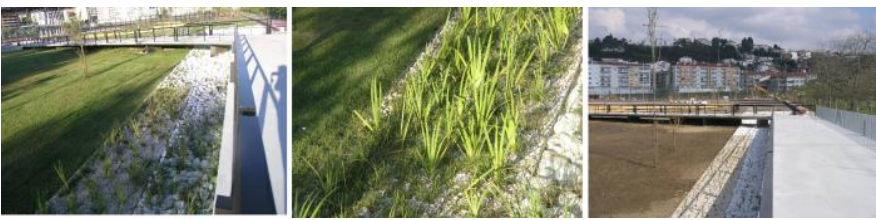

Figure 15. Hidden trench

On this area, all the vegetation belongs to the wet system and is a support to the system stability. Also the herbaceous and bulbous benefit from the water existing in the trench and give colour and textures to the park, as well as the meadow, sometimes wet other dry offering itself for recreation or for contemplation from the dam hidden by the benches. The visual depth that we have from the bridge and walkway or from the park structuring axis is reinforced by shape and matter chosen for their construction. Namely the slab pathway that limits the park at south, invoking a net that is completed with an orchard net and a lattice net that highline the access to the game fields (Fig. 16 and 17).

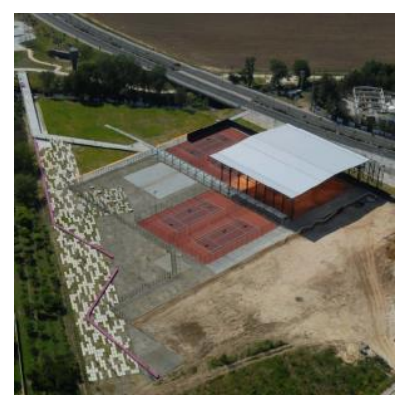

Figure 16. Aerial view over thein construction park area. Photographic credits: Leiria Polis 


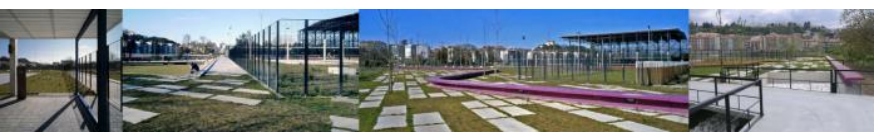

Figure 17. Visual depth. Photographic Credits: Catarina Costa Cabral and Paula Simões

As in north limit the also in south trees are essential. Their presence shapes the voids of the game fields, introduces contrasts in light and shadow as a game that reinforces the pathway rhythm inviting to seat in the long benches that highline the extension of this limit. Here the vegetation searches the continuity of the riparian gallery as it enters formally by the drainage line of the border, going to upstream along the right margin. A volume of autochthonous bushes shapes the "back" of this space giving consistence to the formal physic limit of the project.

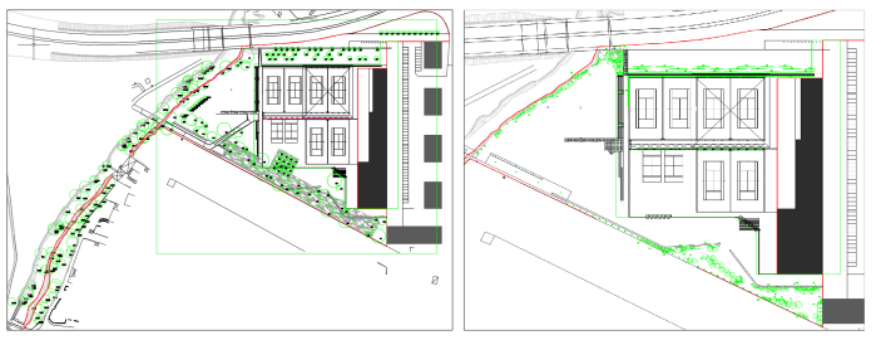

Figure 18. Trees and shrubs plan.

The chosen vegetation is mainly deciduous and heterogeneous. Their changes in time, the different morphologies and colours reinforce the seasons and contrast with the staticity and homogeneity of urban fabric. On the other side they offer a habitat for birds all over the river, the city and its surroundings. The used matter is almost always permeable. The grid grass is a stability support for the herbaceous cover assuring the visual continuity of the park. The furniture and equipment are all over the space. The introduction of deterrent elements in the slope top together with shrubs plantation assures the safety of the users (Fig. 19).
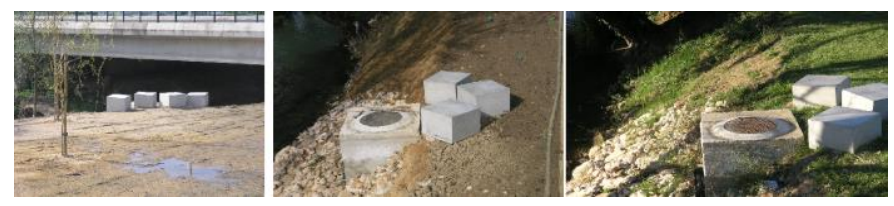

Figure 19. . Deterrents

\section{CONCLUSION}

The S. Romão sportive park is an example of residual areas recovery and its inclusion in a landscape structure, allowing the rehabilitation of a "non-place" [23], that used to be identitary because its agrarian production. The reinvention with new uses in the relation between the man and the river allows its return to population, allows the increase of biodiversity and contributes to the ecologic structure consolidation in Leiria City, articulating the city with the periphery [24]. In Leiria society, like many others disperse and fragmented, contradictory and unpredictable, this landscape can and should become multifunctional unifying a new social contract where development and environment are compatible and together, as well as innovation and history, because the values of culture and quality of life are inherent to them [1].

This project corresponds to Lis river valorisation as a system and respects the biophysical conditions and promote the preservation of landscape history and memory contributing for the improvement of its population quality of life allowing new alternatives to live the city. This project is a proposal of a continuous and structuring fabric that allows the occurrence of ecologic processes. In this proposal are included the ecological, the aesthetical, the social, economic and cultural components, because it is this a set of systems that allows the existence of a multifunctional and integrative landscape. This is a new approach of urban design that establishes positive dialectics between the city, the periphery and between these and the countryside, between the built space and the open spaces and between these and the behaviours and the needs of its populations contributing to the city environment sustainability and its social equity [1].

So, we can consider that with this proposal of landscape structure the city has become to live with and through its open spaces [25]. Now we can recognize new ways of life.

Leiria ecologic structure is today more consolidated by the valorisation of this landscape space that recognizes the river as a fundamental element of complementarity between the consolidated city with its periphery.

\section{REFERENCES}

[1] R. S. Matos, A Reinvenção da multifuncionalidade da paisagem em espaço urbano - reflexões, Tese de Doutoramento, Évora: Universidade de Évora, 2011.

[2] P. M. S. Simões, Guardiões da paisagem - os montes alentejanos. Lugares de memória, Tese de Doutoramento, Évora: Universidade de Évora, 2015.

[3] S. Marot, Sub-urbanism and the art of memory, London: AA Publications, 2003.

[4] J.L. Penelas, J. L. Superlugares - Los Espacios Inter-Media, Madrid: Editorial Rueda S.L, 2007.

[5] C. Waldheim, The Landscape Urbanism Reader. New York: Princeton Architectural Press, 2007.

[6] A. Allen, Environmental planning and management of the peri-urban interface: perspectives on an emerging field. Environment and Urbanization, 15 (1),135, 2003.

[7] M. Mostafavi andC. Najle, Landscape urbanism: a manual for the machinic landscape. London: AA Publications, 2004.

[8] G. Ribeiro Telles, Plano verde de Lisboa. Lisboa: Edições Colibri, 1997.

[9] F. Caldeira Cabral, Fundamentos da arquitectura paisagista. Lisboa: Instituto da Conservação da Natureza, 1993.

[10] R. T. T. Forman, "The Missing Catalyst: Design and Planning with Ecology Roots", in Ecology and Design, B. R. Johnson and K. Hill, Eds. New York: Island Press, 2001.

[11] F. Burel and J. Braudy, Ecologye du Paysage: concepts, méthodes et applications, Paris: Tec \& Doc-Lavoisier, 2001.

[12] E Beveridge and P. Rocheleau. Frederick Law Olmsted: Designing the American Landscape. New York: Universe Publishing, 1998.

[13] A. Spirn, The granite garden: urban nature and human design. New Haven/London: Yale University Press, 1984

[14] M. Hough, Naturaleza y ciudad. Planificación urbana y procesos ecológicos. Barcelona: (Colección Arquitectura y Diseño+Ecologia). Barcelona: Gustavo Gili, 1998.

[15] P. Poullaouec-Godinec, M. Gariépy and B. Lassus. Paysage, le territoire d'intentions, Paris: Harmattan, 1999. 
[16] R.S. Matos, P. Simões and D. Batista, "A paisagem dos arquitectos paisagistas - hotel rural Areias do Seixo" in Leituras Paisagísticas, teoria e praxis, n. 7, C. Terra, J. Andrade and Rubens, Orgs. Rio de Janeiro: EBA/UFRJ, Riobooks, 2017, pp. 23-49.

[17] R. Matos and P. Simões, "Contemporary landscapes:an study of Rabaçal Cstle - Penela - Portugal” pp. 82-86, September 2017 [The $5^{\text {th }}$ Fuman and Social Sciences at the Commomn Conference, Slovakia, p. 124, 2107]

[18] R. Matos and P. Simões, "Holistic approach in integrated lansdcape design - case study for Montalvão Urban Park at Castelo Branco Portugal" pp. 146-153, June 2017 [The $5^{\text {th }}$ International Virtual Conference on Advanced Scientific Results, Slovakia, p. 290, 2017]

[19] M.G.A.N. Saraiva. O rio como paisagem: gestão de corredores fluviais no quadro do ordenamento do território. Lisboa : Fundação Calouste Gulbenkian, Fundação para a Ciência e Tecnologia, 1998.
[20] V.M. Ferreira, F. Indovina (org.). A cidade da Expo' 98: uma reconversão na frente ribeirinha de Lisboa. Lisboa : editorial Bizâncio, 1999.

[21] LeiriaPolis, S.A. Intervenção do programa Polis em Leiria. Leiria: edição sociedade Leiriapolis, 2007.

[22] A.P. Margarido. Leiria: história e morfologia urbana. Leiria: Câmara Municipal de Leiria, 1988.

[23] M. Augè. Não Lugares, introdução a uma antropologia da sobremodernidade. Venda Nova, Portugal: Bertrand Editora.

[24] M. R. Magalhães. Arquitetura Paisagista . Morfologia e Complexidade. Lisboa: Editorial Estampa, 2001

[25] G.R. Telles. Plano Verde de Lisboa. Lisboa, 1997. 